\title{
A bibliometric analysis of food studies: Evidence from British Food Journal
}

\author{
Mert Öğretmenoğlu*, Sevinç Göktepe, Ozan Atsız
}

\author{
Keywords: \\ Food, \\ Food studies, \\ British Food Journal, \\ Bibliometric analysis, \\ VOSviewer software, \\ Web of Science
}

\section{Article History:}

Submitted: 07.05.2021

Revised: 09.08.2021

Revised: 24.10.2021

Accepted: 18.11.2021

Published Online: 20.11.2021

\begin{abstract}
The objective of the current study is to overview the British Food Journal publications from 2010 to 2020. To address our purpose, bibliometric and visualization analyses were used. Firstly, a total of 1892 documents published from 2010 to 2020 in the British Food Journal (BFJ) was obtained from the Web of Science database (WoS). Then, the analyses were made by running VOS viewer software. In the process of analyzing data, we have principally considered some bibliometric indicators such as the number of annual publications, the most productive organizations, the most cited papers, the most contributing countries, the most productive authors, the co-occurrence of author keywords, the coauthorship of countries, and the co-citation of authors. The results show that BFJ is one of the leading and prominent journals with the number of publications increasing each year according to the basic indicators mentioned above. Further to this, the most productive and contributing authors, institutions, and countries are mainly from European countries. The most common researched fields according to the co-occurrence of author keywords are listed as "consumer behavior, food safety, food products, food industry, food, nutrition, organic food, sustainability, and consumer".
\end{abstract}

Doi: https://doi.org/10.31822/jomat.2022-7-1-67

\section{Introduction}

Food is a key attraction that pushes travelers to visit a destination. During the decision-making process, travelers consider these attractions while traveling to a destination. Thus, the link between tourism and food is evident and this was approved by many tourism and hospitality scholars. According to Hall and Sharples (2003, p.10), food tourism is defined as "visitation to primary and secondary food producers, food festivals, restaurants and specific locations for which food tasting and/or experiencing the attributes of specialist food production region are the primary motivating factor for travel." Many researchers investigated food studies, therefore, great knowledge on this topic exists in the research stream (Akova et al., 2016; Atsız et al., 2021; Çifçi et al., 2021; Ellis et al., 2018). To make a synthesis and bring together knowledge of food studies, this paper attempt to compile previous research published in the British Food Journal.
The British Food Journal (hereafter BFJ) is a journal that releases articles including case studies and literature reviews, empirical and applied researches, viewpoint articles, and general reviews from all disciplines relating to the consumption, business, management, and marketing, health, welfare, and education, sustainability, and environment. The main scope of the journal is food. BFJ is a basic journal for those who are interested in food such as researchers, academics, students in social science, management, public health disciplines. Additionally, dietitians and nutritionists, food and agricultural companies, food research institutes, professionals who work in the food industry could benefit from this journal. BFJ released its first issue in 1899. Its first publisher was Bailliere, Tindall \& Cox, but its publishing is currently undertaken by Emerald Publishing Limited. As a hybrid and monthly journal, BFJ has 1283 issues in 123 volumes so far. It is indexed in databases such as Science Citation Index, Scopus, and Hospitality and Tourism Index (Emerald, 2021). According to Scopus and Clarivate

Mert Ö̆̆retmenoğlu: Research Assistant (PhD Candidate), Istanbul University, Istanbul, Turkey, Email: mert.ogretmenoglu@istanbul.edu.tr, Orcid Id: 10000-0003-0639-4891 (iD

Sevinç Göktepe : Asst. Prof(PhD), Istanbul University, Istanbul, Turkey, Email: goktepe@istanbul.edu.tr, Orcid Id: 0000-0002-0856-0278 ii

Ozan Atsız: Research Assistant (PhD), Bozok University, Yozgat, Turkey, Email: ozan.atsiz@bozok.edu.tr, Orcid Id: 0000-0003-29621903 (iD) 
Analytics, its Cite Score is 3.1 in 2019 (Scopus, 2021), and its five-year impact factor is 2.467 respectively (Clarivate, 2021). Today, BFJ has a long publishing background in food research with 122 years of history. Although it is a highly respected worldwide interdisciplinary journal (Scimagojr, 2021), to the best of our knowledge, no research that analysis of the papers of the BFJ that published between 2010 and 2020 by bibliometric approach.. Therefore, the scope of this study is to evaluate the papers published in BFJ between 2010 and 2020 with bibliometric analysis. Although thousands of articles have been published in the BFJ since 1899, to understand trends and changes in current food studies, we only evaluated documents from 2010 to 2020. To achieve this purpose, we use the WoS database which is one of the most popular (Mongeon \& PaulHus, 2016), important (Van Leeuwen, 2006), and reliable (Ozsoy \& Demir, 2018) source of data for bibliometric studies. There are some reasons why we preferred WoS database in this research. Firstly, it is aimed at reducing the possibility of analysing the same studies more than once. Secondly, many researchers collected data from WoS for bibliometric analyses (Mavric et al., 2021).

This bibliometric research has some important implications for BFJ and relevant literature. Firstly, the examination of a journal with the bibliometric method is important as it presents historical information about both the impact of that aforementioned journal and its evolutionary development (Schwert, 1993). Secondly, the results of bibliometric analysis of journals can be extremely useful for editorial boards to make some decisions on the further development of journals (Mokhtari et al., 2020). Thirdly, it can give new ideas to researchers studying food research. Additionally, many studies examine journals through a bibliometric approach in various fields of social sciences (Merigó et al., 2019). For example, in the field of business and marketing, MartínezLópez et al. (2018) studied the European Journal of Marketing for fifty years. Another examples, a bibliometric review to analyze forty-five years of publications in the Journal of Business Research conducted by Donthu et al. (2020). Similarly, in the field of hospitality and tourism, Mulet-Forteza et al. (2018) made a bibliometric overview of the twenty-five years of the Journal of Travel \& Tourism Marketing. Cunill et al. (2019) used a bibliometric method for measuring the scientific performance of the International Journal of Hospitality Management. Sharma et al. (2020) examined the Journal of Teaching in Travel \&
Tourism from 2001 to 2019 through a bibliometric approach. Based on these examples, this study is structured as follows. The second section of the study explains bibliometric analysis and describes methods applied through this research. Then, the third section presents the obtained results. The last sections include a conclusion, limitations, and suggestions for further research.

\section{Bibliometric analysis and Method}

Most of the scholars are familiar with the bibliometric methods as applied to scientific papers (Narin, 1994). This method compounds various categories and ranges from research papers, patents, and books to the reports which are categorized as grey literature (Ellegaard \& Wallin, 2015). Abstract services and databases on the internet make electronic documents more accessible (Morris et al., 2002), making bibliometric research much practical (Patra et al., 2006). Although it looks like a new technique, bibliometric analysis has been on the agenda of researchers for a long time. One of the first definitions of bibliometric analysis belongs to Pritchard. Pritchard (1969, p. 349) defined bibliometric analysis as "the application of mathematics and statistical methods to books and other media of communication". Broadus (1987, p. 376) also described it as "bibliometric is the quantitative study of physical published units, or of bibliographic units, or of the surrogates for either." Briefly, bibliometric is "the use of statistical analyses to study publication patterns" (McBurney \& Novak, 2002, p.109). Bibliometric methods are mostly used to measure the effects of academic papers (Cooper, 2015). According to Cronin (2001), bibliometric count and measure things that they consider more visible and objective indicators of scholarly activity, especially publications and citations. Bibliometric offers powerful methods and measures to study the structure and process of scientific communication (Borgman \& Furner, 2002). Bibliometric methods also allow researchers to discover and analyze historical data that can help in identifying "hidden patterns" in the decision-making process (Daim et al., 2006). Besides all these, these methods are economical, non-intrusive, and easy to implement, which allow updates and fast intertemporal comparisons (Abramo et al., 2009).

Bibliometric methods consist of various methodologies (McBurney \& Novak, 2002). These methods were created to measure the flow of information between countries, disciplines, and individual working groups and to evaluate the 
productivity of different organizations, taking into account the number of citations, documents, and other text-based data (Kurtz \& Bollen, 2010). Bibliometric methods also predict how effective the selected articles will be on future researches by looking more at the citation number of the article (Cooper, 2015). Bibliometric contain word frequency analysis, co-citation analysis, co-word analysis, co-authorship, co-occurrences, and simple countings, such as the total number of publications by an author or country (Thelwall, 2008). Cocitation analysis, one of the best known bibliometric methods (Borgman \& Furner, 2002; Osareh, 1996), looks at the relationship (include field, authors, institutions, and countries) between a paper and the papers it has cited (McBurney \& Novak, 2002). Co-occurrence is an author collaboration network that reflects scholarly communication (Qiu et al., 2014). With cooccurrence analysis, interdisciplinary participation and collaboration in a particular research area can be examined (Liu \& Mei, 2016). Co-authorships also can be considered as codified markers of research collaboration (Park et al., 2016; Ponomariov \& Boardman, 2016).

In addition, this study is based on previous studies that analyzed journals with a bibliometric approach. Such researchers like, Chen et al. (2017); Martínez-Lopez et al. (2018); Vishwakarma \& Mukherjee, 2019 ; Xu \& Yu (2019); Gaviria-Marin et al. (2018); Wang et al. (2020) made a bibliometric study of articles which they used such methods like it is mentioned above. In this paper, we analyzed the number of annual publications, the most productive organizations, the most cited papers, the most productive authors, the most contributing countries, the co-occurrence of author keywords, co-authorship of countries, and co-citation of authors. In addition, in the data analysis process, we used VOS viewer which has a powerful user graphic-interface and mapping visualization capability (Wang et al., 2020).

\section{Sampling and Software}

BFJ's documents are available on both Scopus and WoS databases. However, in this study, we obtained the data from the WoS database on 28 January 2021. We have taken into account the studies scanned in only WoS as there is a possibility that the same articles are included in both WOS and Scopus and to avoid analyzing the same data incorrectly (Mavric et al., 2021).

To define the sample, the keyword "British Food Journal" was used. The search was done in the "publication name" field. At the end of this process (step 1), we found 2239 documents such as articles, reviews, and editorial material in the WoS database (See figure 1). Since the scope of this study is to examine the documents published between 2010 and 2020, the documents were searched again in the search engine and reached 1892 studies published in the relevant years. These obtained data were analyzed by Vosviewer software.

VOSviewer originated by Jan van Eck and Ludo Waltman in order to construct and view bibliometric visual maps (Van Eck \& Waltman, 2010). VOSviewer is software used in both constructing and visualizing bibliometric networks such as researchers, journals, or individual publications. Moreover, VOSviewer can analyze data obtained by Web of Science, Scopus, Dimensions, and PubMed (VOSviewer, 2020). It is used as a software that is frequently used in specific journal reviews (e.g. Martínez-Lopez et al., 2018; Gaviria-Marin et al., 2018; Mulet-Forteza et al., 2018; Vishwakarma \& Mukherjee, 2019; Merigó et al., 2019; Kumar et al., 2020; Sharma et al., 2020; Mokhtari et al., 2020; Wang et al., 2020). Based on the above previous studies, in the present study, Vosviewer was chosen for the analysis of the data (Mavric et al., 2021).
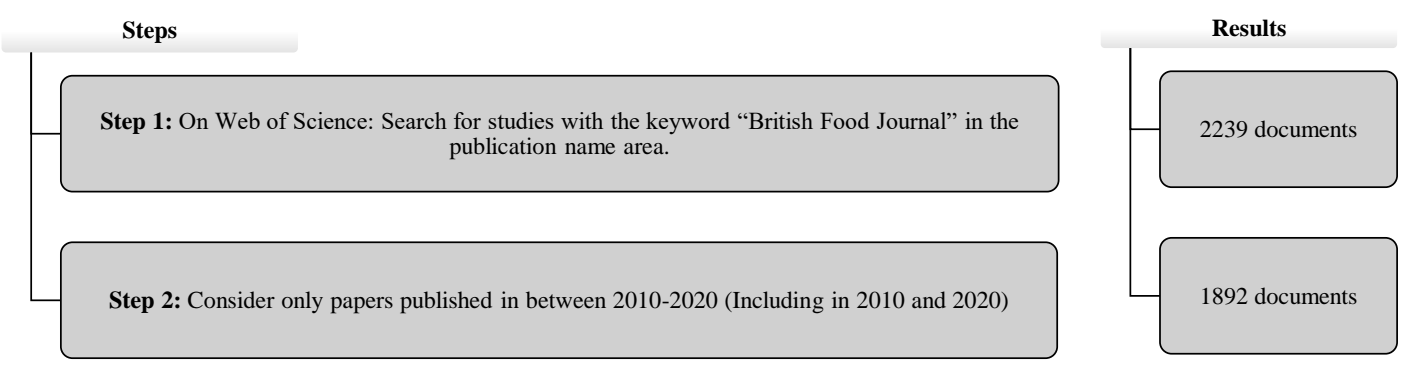

Figure 1. Flowchart of the selection of the studies 


\section{lomat}

\section{Results}

The Annual number of BFI publications by year

Figure 2 shows the papers published in the BFJ between the years 2010 and 2020 . When figure 2 is viewed, it is seen that more papers are published each year compared to the previous year. Especially the number of studies published in 2019 and 2020 is remarkable. While the journal published 88 studies in 2010, this number increased to 300 in 2020. From this point of view, it can be said that the BFJ is growing day by day and its popularity increases among authors who study on food.

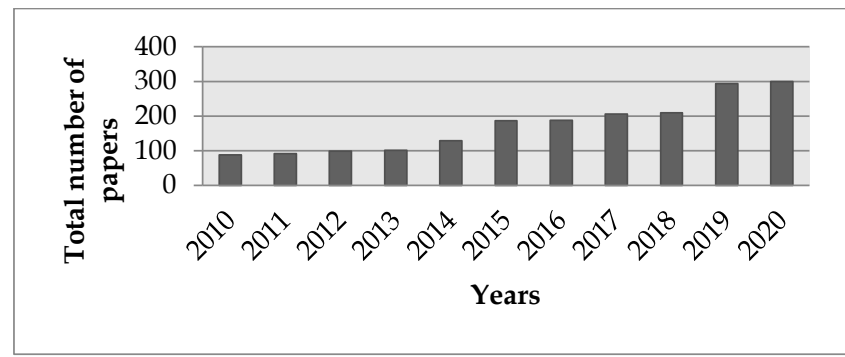

Figure 2. Total number of BFJ publications by year (20102020)

Source: Authors

\section{The Most Productive Authors}

Figure 3 indicates the ten most productive authors in BFJ. According to the publishing count, the most productive author is Alonso A. D publishing 15 papers, followed by authors, Gellynck X, Manning L, Djekic I, Soon J. M, Spiller A.

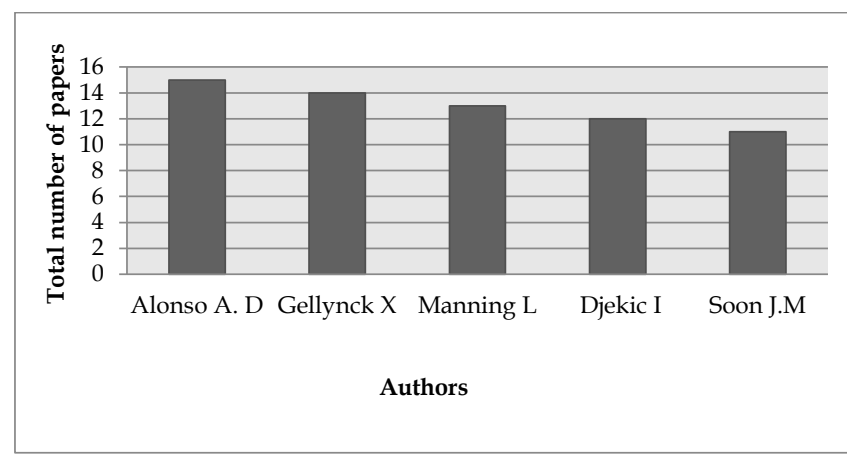

Figure 3. Authors who published the most documents in the BFJ (Note: The top 5 authors who published the most Source: Authors documents in this journal were selected)

Abel Duarte Alonso (h-index $=21$ ) has the highest number of published articles in BFJ (15 papers). He published 5 articles in 2010, 6 articles in 2011, 1 article in 2012, 1 article in 2013, 1 article in 2015, and 1 article in 2020 . He conducted his research on wine.

\section{Mert Öğretmenoğlu, Sevinç Göktepe, Ozan Atsız}

Xavier Gellynck ( $h$-index $=31$ ) is the second author to have published the most studies in this journal. He published 1 study in 2012, 1 study in 2014, 3 studies in 2015, 4 studies in 2016, 1 study in 2017, 1 study in 2018, 2 studies in 2019, and 1 study in 2020. He carried out his research on consumer behaviors, consumer, and traditional food.

Louise Manning ( $h$-index $=9$ ) is the third most published author in BFJ (12 articles and 1 editorial material). She published 1 document in 2012, 5 documents in 2013, 1 document in 2015, and a total of 6 documents in 2016, 2017, and 2019. She conducted her research on food safety, food supply chain, and food safety risk.

Ilija Djekic ( $h$-index $=16$ ) has 12 documents in BFJ (12 articles and 1 review). He published his first article in this journal in 2015. His last article was published in 2020 . He carried out his research on food safety and supply chain.

Jan Mei Soon (h-index $=14$ ) is a Ph.D. in Food Safety and she has 11 articles in BFJ. She conducted her research on food crime, food supply chain, food safety risk, and halal slaughter.

In general, it is seen that these researchers focused their research on two main topics; food supply chain and food safety.

\section{The Most Productive Organizations}

Figure 4 demonstrates the institutions that have published the most studies in the BFJ. From the viewpoint of productivity, Wageningen University Research (with 53 papers) is the most productive institution, followed by the University of Turin (with 33 papers).

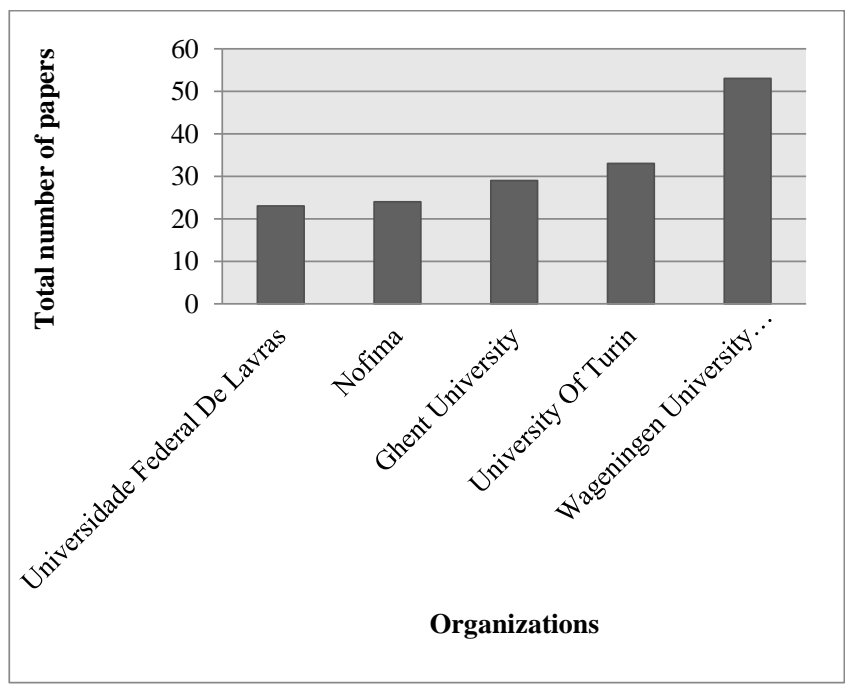

Figure 4. Organizations that published the most documents in the BFJ (Note: The top 5 organizations which published the Source: Authors 
Wageningen University and Research is located in the Netherlands and it has Tourism and Food technology undergraduate programs (Wageningen University and Research, 2021). This university has the highest number of published studies with 53 papers published in BFJ. This number constitutes $2.8 \%$ of the total 1892 papers published in 2010-2020.

The University of Turin is one of the oldest universities in Europe and it is located in Italy. The University has a Department of Agricultural, Forest, and Food Sciences (University of Turin, 2021). It is the second university to have published the most studies in this journal. This university contributed 33 papers to the BFJ (1.7\% of the total documents).

Ghent University is one of the major universities in Belgium. This university has a Master of Food Technology program (Ghent University, 2021). It is the third most published organization in BFJ (29 articles).

Nofima is located in Norway and it is a prestigious and leading institute for applied research within the field of food research. Its basic vision is "Sustainable food for all" (Nofima, 2021).This institute published 24 papers in BFJ.

Universidade Federal De Lavras is a university operating in Brazil. It has graduate programs such as Food Science and it has undergraduate programs such as Food Engineering and Nutrition (Universidade Federal De Lavras, 2021). This university contributed 23 papers to the BFJ.
In summary, 4 of the most productive organizations in this journal are of European origin. Only one organization is located outside of Europe.

\section{The Most Contributing Countries (Top 25)}

In this section, we have analyzed some countries that have contributed the most in terms of the total number of documents published in BFJ. Figure 5 illustrates the distribution of countries contributing to BFJ. As can be seen on the map below, Italy comes first. Italy published 247 documents (13.05 \%). After Italy, England ranks second and the USA ranks third. These countries have published $183(9.6 \%)$ and $166 \quad(8.7 \%)$ documents, respectively. The subsequent countries include Brazil (4th, 120 papers), Australia (5th, 107 papers), Germany (6th, 105 papers), Spain (7th, 100 papers), China (8th, 93 papers), Malaysia (9th, 82 papers), Netherlands (10th, 66 papers), Canada (11th, 65 papers), India (12th, 61 papers), Taiwan (13th, 56 papers), Turkey (14th, 52 papers), Norway (15th, 51 papers), Poland (16th, 50 papers), Denmark (17th, 48 papers), South Africa (18th 44 papers), Sweden (19th, 37 papers), Belgium (20th, 36 papers), France (21st 36 papers), Greece (22nd, 35 papers), New Zealand (23rd, 34 papers), Finland (24th, 33 papers) and Ireland (25th, 32 papers). In summary, sixteen of the most contributing countries are located in Europe, three in America (Both north and south), five in Asia, and two in Oceania. In addition, there is only one country from the African continent.

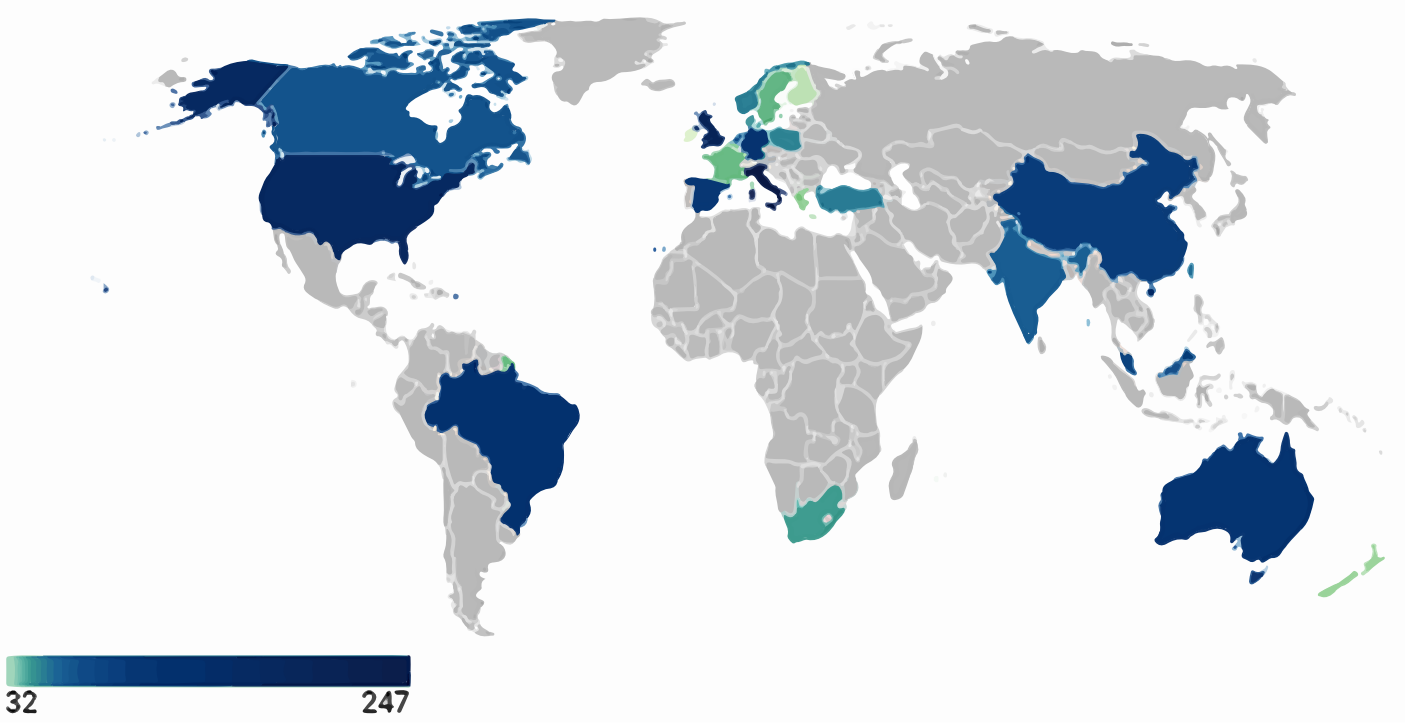

Figure 5. The most contributing countries (Note: The top 25 countries which published the most documents in this journal were selected). 
Table 1. The most cited documents in BFJ

\begin{tabular}{|c|c|c|c|c|c|c|}
\hline Rank & Authors & Title & Method & Type & 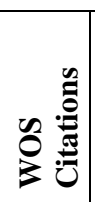 & 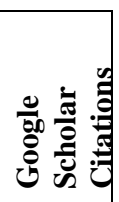 \\
\hline 1 & $\begin{array}{l}\text { Aertsens et al. } \\
(2011)\end{array}$ & $\begin{array}{l}\text { The influence of subjective and objective } \\
\text { knowledge on attitude, motivations, and } \\
\text { consumption of organic food. }\end{array}$ & $\begin{array}{l}\text { Quantitative } \\
\text { (Questionnaire) }\end{array}$ & Article & 156 & 488 \\
\hline 2 & $\begin{array}{l}\text { Zakowska- } \\
\text { Biemans (2011) }\end{array}$ & $\begin{array}{l}\text { Polish consumer food choices and beliefs about } \\
\text { organic food }\end{array}$ & $\begin{array}{l}\text { Quantitative } \\
\text { (Questionnaire) }\end{array}$ & Article & 108 & 284 \\
\hline 3 & $\begin{array}{l}\text { Vrontis et al. } \\
(2016)\end{array}$ & $\begin{array}{l}\text { Tradition and Innovation in Italian Wine Family } \\
\text { Businesses }\end{array}$ & Case study & Article & 103 & 148 \\
\hline 4 & $\begin{array}{l}\text { Pearson et al. } \\
(2011)\end{array}$ & $\begin{array}{l}\text { Local food: understanding consumer } \\
\text { motivations in innovative retail formats }\end{array}$ & $\begin{array}{l}\text { Quantitative } \\
\text { (Questionnaire) }\end{array}$ & Article & 100 & 240 \\
\hline 5 & $\begin{array}{l}\text { Al-Swidi et al. } \\
(2014)\end{array}$ & $\begin{array}{l}\text { The role of subjective norms in theory of } \\
\text { planned behavior in the context of organic food } \\
\text { consumption }\end{array}$ & $\begin{array}{l}\text { Quantitative } \\
\text { (Questionnaire) }\end{array}$ & Article & 95 & 252 \\
\hline 6 & $\begin{array}{l}\text { Principato et al, ( } \\
\text { 2015) }\end{array}$ & $\begin{array}{l}\text { Reducing food waste: an investigation on the } \\
\text { behaviour of Italian youths }\end{array}$ & $\begin{array}{l}\text { Quantitative } \\
\text { (Questionnaire) }\end{array}$ & Article & 90 & 152 \\
\hline 7 & $\begin{array}{l}\text { Teng \& Wang } \\
(2015)\end{array}$ & $\begin{array}{l}\text { Decisional factors driving organic food } \\
\text { consumption: Generation of consumer purchase } \\
\text { intentions }\end{array}$ & $\begin{array}{l}\text { Quantitative } \\
\text { (Questionnaire) }\end{array}$ & Article & 86 & 225 \\
\hline 8 & Horst et al. (2014) & $\begin{array}{l}\text { The "dark side" of food banks? Exploring } \\
\text { emotional responses of food bank receivers in } \\
\text { the Netherlands }\end{array}$ & $\begin{array}{l}\text { Qualitative } \\
\text { (Interview) }\end{array}$ & Article & 82 & 153 \\
\hline 9 & $\begin{array}{l}\text { Silvennoinen et al. } \\
(2014)\end{array}$ & $\begin{array}{l}\text { Food waste volume and composition in Finnish } \\
\text { households }\end{array}$ & $\begin{array}{l}\text { Quantitative } \\
\text { (Questionnaire) }\end{array}$ & Article & 77 & 173 \\
\hline 10 & Dora et al. (2014) & $\begin{array}{l}\text { Application of lean practices in small and } \\
\text { medium-sized food enterprises }\end{array}$ & $\begin{array}{l}\text { Qualitative } \\
\text { (Questionnaire) }\end{array}$ & Article & 74 & 141 \\
\hline 11 & $\begin{array}{lll}\text { Griffith } & \text { et } & \text { al. } \\
(2010 \mathrm{a}) & & \\
\end{array}$ & The assessment of food safety culture & $\begin{array}{l}\text { Conceptual/Lit } \\
\text { erature review }\end{array}$ & Article & 71 & 137 \\
\hline 12 & Xie et al. (2015) & $\begin{array}{l}\text { Consumer perceptions and attitudes of organic } \\
\text { food products in Eastern China }\end{array}$ & $\begin{array}{l}\text { Mixed } \\
\text { (Quantitative } \\
\text { and } \\
\text { Qualitative) }\end{array}$ & Article & 69 & 138 \\
\hline 13 & $\begin{array}{l}\text { Vanhonacker et al. } \\
(2010)\end{array}$ & Profiling European traditional food consumers & $\begin{array}{l}\text { Quantitative } \\
\text { (Questionnaire) }\end{array}$ & Article & 69 & 141 \\
\hline 14 & $\begin{array}{l}\text { Santoro et al. } \\
(2017)\end{array}$ & $\begin{array}{l}\text { External knowledge sourcing and new product } \\
\text { development: Evidence from the Italian food } \\
\text { and beverage industry }\end{array}$ & $\begin{array}{l}\text { Quantitative } \\
\text { (Questionnaire) }\end{array}$ & Article & 68 & 87 \\
\hline 15 & $\begin{array}{l}\text { Röös \& Tjärnemo } \\
(2011)\end{array}$ & $\begin{array}{l}\text { Challenges of carbon labelling of food products: } \\
\text { a consumer research perspective }\end{array}$ & $\begin{array}{l}\text { Conceptual/Lit } \\
\text { erature review }\end{array}$ & Article & 64 & 118 \\
\hline 16 & $\begin{array}{l}\text { Wiedmann et al. } \\
\text { (2014) }\end{array}$ & $\begin{array}{l}\text { Tasting green: an experimental design for } \\
\text { investigating consumer perception of organic } \\
\text { wine }\end{array}$ & $\begin{array}{l}\text { Quantitative } \\
\text { (questionnaire) }\end{array}$ & Article & 62 & 103 \\
\hline 17 & $\begin{array}{l}\text { Dimitri \& } \\
\text { Dettmann (2012) }\end{array}$ & $\begin{array}{l}\text { Organic Food Consumers: what do we really } \\
\text { know about them? }\end{array}$ & $\begin{array}{l}\text { Quantitative } \\
\text { (Econometric } \\
\text { model) }\end{array}$ & Article & 62 & 165 \\
\hline 18 & $\begin{array}{l}\text { Griffith et al. } \\
(2010 b)\end{array}$ & $\begin{array}{l}\text { Food safety culture: the evolution of an } \\
\text { emerging risk factor? }\end{array}$ & $\begin{array}{l}\text { Conceptual/Lit } \\
\text { erature review }\end{array}$ & Article & 61 & 135 \\
\hline 19 & $\begin{array}{l}\text { Franceschelli et al. } \\
(2018)\end{array}$ & $\begin{array}{l}\text { Business model innovation for sustainability: a } \\
\text { food start-up case study }\end{array}$ & Case study & Article & 60 & 87 \\
\hline 20 & $\begin{array}{l}\begin{array}{l}\text { Tarasuk et } \\
(2014)\end{array} \\
\end{array}$ & $\begin{array}{l}\text { Food banks, welfare, and food insecurity in } \\
\text { Canada }\end{array}$ & $\begin{array}{l}\text { Conceptual/Lit } \\
\text { erature review }\end{array}$ & Article & 60 & 119 \\
\hline
\end{tabular}

Source: (It was created by researchers using WoS Database) 
The most cited documents in BFI publications (Top 20) This section examines the most cited papers published in BFJ according to the WoS database. Table 1. indicates the Top 20.

The most cited paper of the journal was published in 2011 by Aertsens et al. on organic food consumption. It currently has more than 156 citations. Looking at the 20 most-cited documents, it is seen that they are mainly research articles. The quantitative method was used in most of the studies (12). Aertsens et al. (2011); ZakowskaBiemans (2011); Al-Swidi et al. (2014); Teng \& Wang, (2015); Xie et al. (2015); Wiedmann et al. (2014) and Dimitri \& Dettmann (2012) have focused on organic food products, organic food consumption, and consumer choice about organic food in their studies. Griffith et al. made two papers about food safety in 2010 which have 71 and 61 citations respectively. Principato et al. (2015) and Silvennoinen et al. (2014) studied food waste; Horst et al. (2014) and Tarasuk et al. (2014) made researches about food banks. The other research subjects are Italian wine family business by Vrontis et al. (2016); consumer motivations about local food by Pearson et al. (2011); lean practices in small and medium-sized food enterprises by Dora et al. (2014); European food consumers by Vanhonacker et al. (2010); new food product development by Santoro et al. (2017); challenges of carbon labeling of the food product by Röös \& Tjärnemo (2011) and business model innovation by Franceschelli et al. (2018).

\section{Science mapping analysis of British Food Journal}

In this section, we made a science mapping analysis of papers in the British Food Journal. We analyzed the co-occurrence of author keywords, coauthorship of countries, and co-citation of authors by VoSviewer.

Co-occurrence of author keywords of documents published in the BFJ: To figure out the main research topics of the papers in journals, $\mathrm{co}^{-}$ occurrence analysis of keywords is an influential and considerable analysis to obtain an appearance of the knowledge structure and actual research trend (Wang et al., 2020). In this direction, we analyzed the co-occurrence of author keywords to determine the research trends in BFJ. Figure 6 shows the author's keyword co-occurrence of keywords listed in Table 2. Although there are 4992 keywords of papers in the BFJ from 2010 to 2020, only 331 keywords meet the threshold. Out of the keywords, consumer behavior (181), food safety (104), food products (99), food industry (64), food (64), nutrition (50), organic food (49), consumers (40), sustainability (40) and wine (35) are ranked as the most foremost keywords that are consisted more than 5 times in BFJ papers.

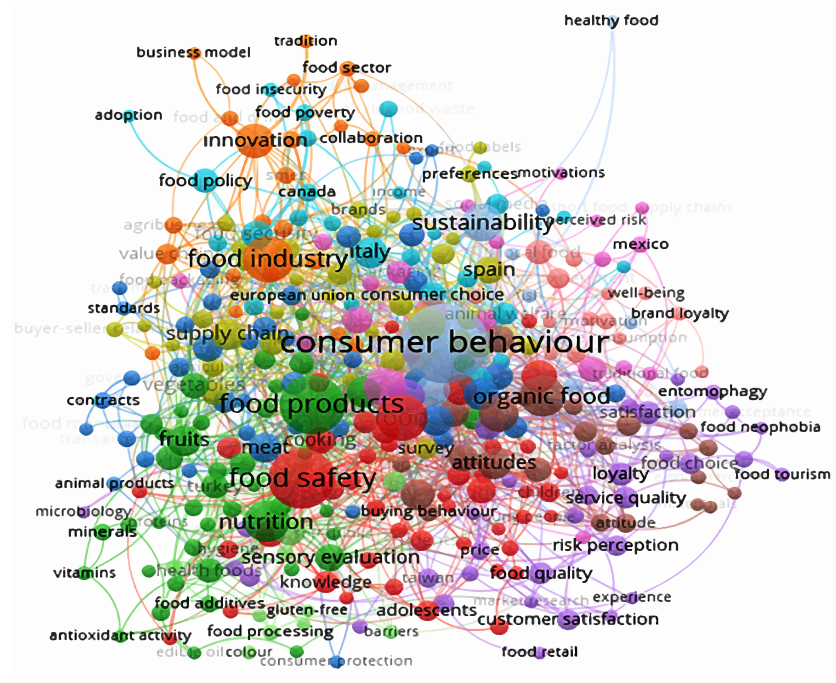

Figure 6. Co-occurrence of author keywords of papers published in BFJ

Source: Authors

It is also worth noting that; a node demonstrates a keyword. Big node means that keyword has more citations. A link between two nodes signifies the co- $^{-}$ occurrence of two keywords. The coarser line means that they have more co-occurred times. Additionally, a color symbolizes a cluster (Wang et al., 2020). As a result of this analysis, we obtained 12 clusters (See figure 6). (1) The red cluster consists of keywords such as food safety, healthy, food consumption, HACCP, restaurant, and catering. (2) Yellow cluster occurs keywords such as food products, nutrition, fruits, vegetables, proteins, and dairy products. (3) Green cluster occurs keywords such as food products, nutrition, fruits, vegetables, proteins, and dairy products. (4) The supply chain, Spain, the USA, buyer-seller relationships are prominent in the yellow cluster; (5) willingness to pay and purchase intention foremost keywords in the blue cluster; (6) keywords such as satisfaction, loyalty, and service quality stood out in the purple cluster. (7) Food policy, Canada, Italy, and Food security are highlighted in the turquoise cluster. The food industry and innovation are some of the keywords that dominate the orange cluster. (8) The brown cluster consists of words such as organic food, attitudes, and consumer attitudes. (9) The light purple cluster consists of words such as marketing, packaging, and retailing. (10) Local food predominates in the pink cluster. (11) Customer preferences come first in the light green cluster. (12) In the light blue 
cluster, consumer behavior, customer perspective, consumer research, fish, and fresh fish are the dominant keywords.

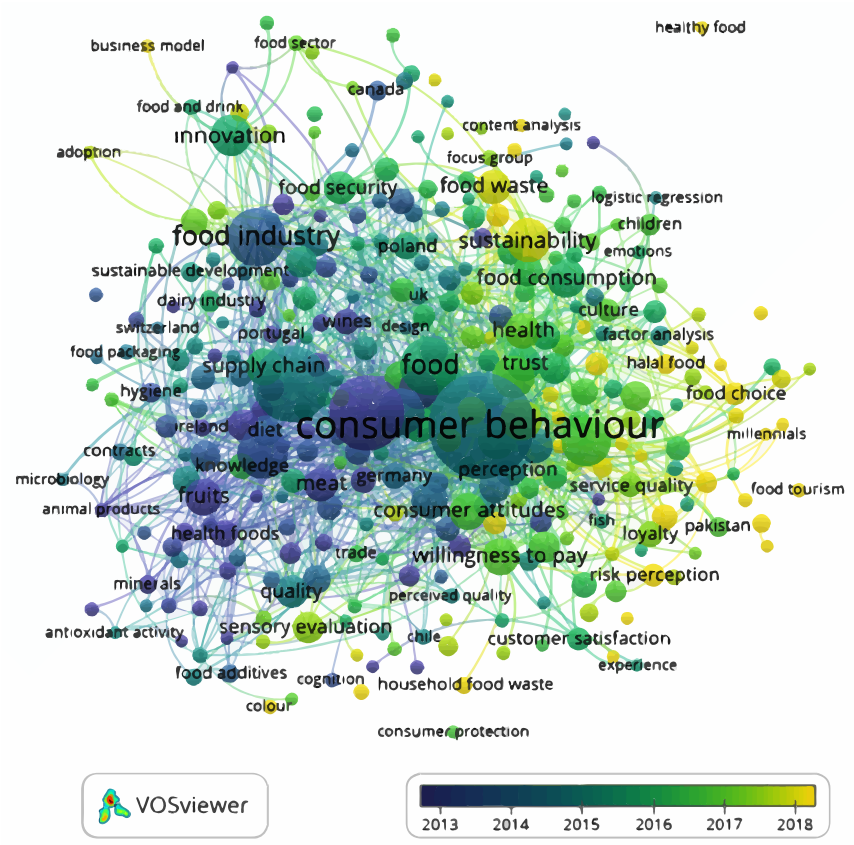

Figure 7. A timeline view of co-occurrence of author keywords of papers published in BFJ

Source: Authors

In addition, the figure above (figure 7) shows in which years the keywords were studied most. When Figure 7 is examined, it shows that the authors who published in this journal researched food production, healthy food, fruits, minarets, hygiene, organic foods, customer behavior, food industry, and supply chain between 2013 and 2016 . However, after 2018, it is observed that the authors mostly investigated topics such as sustainability, food waste, household food waste, wine, halal food, food tourism, perceived risk, and food choice.

\section{Co-authorship of countries that publish in the BFJ:}

Co-authorship of countries implies that authors from different countries publishing jointly (Kumar et al., 2020). The co-authorship network among countries is presented in Figure 8. The network analysis shows that Spanish authors cooperate mostly with co-authors from Chile, Colombia, Mexico, Egypt, Morocco, Pakistan, Saudi Arabia, Tunisia, and Wales (Red Cluster). There are powerful collaborative linkages among Australia, Indonesia, Ireland, Japan, Netherlands, New Zealand, North Ireland, Scotland, Taiwan, and Vietnam (Green Cluster). Countries in the blue cluster are; Bangladesh, Belgium, Germany, Hungary, Israel, the People's Republic of China,
Table 2. The most common keywords in BFJ

\begin{tabular}{|c|c|c|c|}
\hline Rank & Keyword & Occurrences & $\begin{array}{l}\text { Total link } \\
\text { strength }\end{array}$ \\
\hline 1 & Consumer Behavior & 181 & 174.00 \\
\hline 2 & Food Safety & 104 & 88.00 \\
\hline 3 & Food Products & 99 & 94.00 \\
\hline 4 & Food Industry & 64 & 58.00 \\
\hline 5 & Food & 64 & 60.00 \\
\hline 6 & Nutrition & 50 & 45.00 \\
\hline 7 & Organic Food & 49 & 45.00 \\
\hline 8 & Consumers & 44 & 44.00 \\
\hline 9 & Sustainability & 40 & 32.00 \\
\hline 10 & Wine & 35 & 32.00 \\
\hline 11 & Innovation & 35 & 27.00 \\
\hline 12 & Organic Food & 33 & 30.00 \\
\hline 13 & China & 31 & 26.00 \\
\hline 14 & Food Consumption & 30 & 26.00 \\
\hline 15 & Consumer Attitudes & 29 & 28.00 \\
\hline 16 & Fruits & 29 & 28.00 \\
\hline 17 & Consumption & 29 & 27.00 \\
\hline 18 & Willingness To Pay & 29 & 27.00 \\
\hline 19 & Supply Chain & 29 & 26.00 \\
\hline 20 & Consumer Perceptions & 28 & 26.00 \\
\hline 21 & Health & 28 & 28.00 \\
\hline 22 & Attitudes & 27 & 26.00 \\
\hline 23 & Trust & 27 & 27.00 \\
\hline 24 & Italy & 27 & 22.00 \\
\hline 25 & Food Waste & 26 & 20.00 \\
\hline 26 & Meat & 25 & 22.00 \\
\hline 27 & Quality & 23 & 20.00 \\
\hline 28 & Food Security & 23 & 19.00 \\
\hline 29 & Labeling & 22 & 21.00 \\
\hline 30 & $\begin{array}{l}\text { Supply Chain } \\
\text { Management }\end{array}$ & 22 & 21.00 \\
\hline 31 & Perception & 22 & 22.00 \\
\hline 32 & Cluster Analysis & 22 & 19.00 \\
\hline 33 & Spain & 22 & 21.00 \\
\hline 34 & Cooking & 22 & 20.00 \\
\hline 35 & Sensory Evaluation & 22 & 17.00 \\
\hline 36 & Purchase İntention & 22 & 15.00 \\
\hline 37 & Marketing & 21 & 20.00 \\
\hline 38 & Diet & 21 & 19.00 \\
\hline 39 & Vegetables & 20 & 19.00 \\
\hline 40 & Restaurants & 20 & 19.00 \\
\hline 41 & $\begin{array}{l}\text { Theory of Planned } \\
\text { Behavior }\end{array}$ & 20 & 19.00 \\
\hline 42 & Consumer Choose & 18 & 18.00 \\
\hline 43 & India & 18 & 18.00 \\
\hline 44 & Turkey & 18 & 16.00 \\
\hline 45 & Local Food & 18 & 17.00 \\
\hline 46 & Health Foods & 17 & 17.00 \\
\hline 47 & Gender & 17 & 15.00 \\
\hline 48 & Food Policy & 17 & 15.00 \\
\hline 49 & Poland & 17 & 15.00 \\
\hline
\end{tabular}




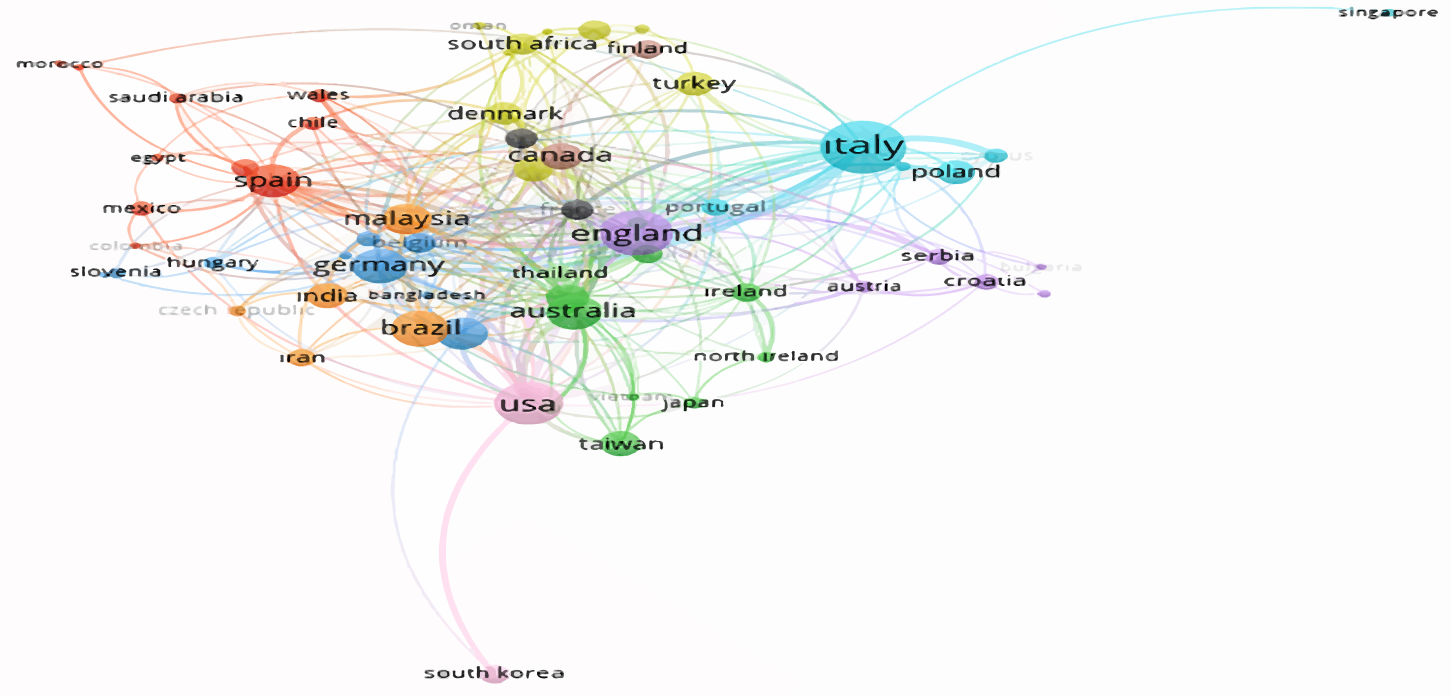

Figure 8. BFJ international collaboration network

Romania, Slovenia, and Switzerland. The countries in the yellow cluster are; Denmark, Kenya, Nigeria, Norway, Oman, South Africa, Sweden, Tanzania, and Turkey. English authors cooperate mostly with co-authors from Austria, Bosnia and Herzegovina, Bulgaria, Croatia, and Serbia (Purple cluster). Italian authors collaborate with Cypriot, Polish, Portuguese, and Russian authors (Turquoise cluster); Brazilian researchers collaborate with Czech, Hindu, Iranian and Malaysian researchers (Orange cluster). Finally, Canadians work jointly with Finns (Brown cluster), Americans with South Koreans (Pink cluster), and French with Greeks (Black cluster).

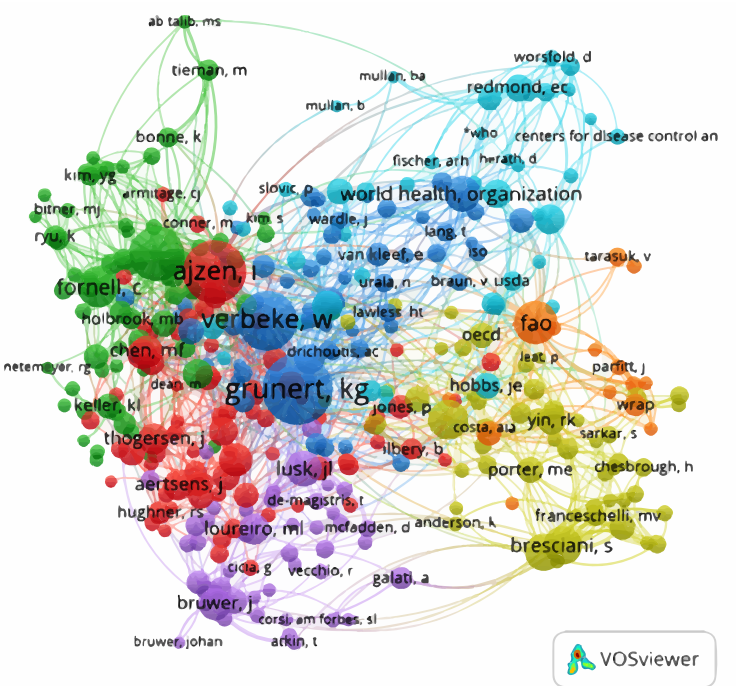

Figure 9. Co-citation network map of authors cited by BFJ Source: Authors

\section{Conclusion}

The number of bibliometric studies in food, tourism and hospitality literature is increasing day by day (e.g. Evren \& Kozak, 2014; Hall, 2011; Köseoglu et al., 2015; Okumus et al., 2018; Lyu et al., 2020; Vila-Lopez \& Küster-Boluda, 2020). According to these studies, a wealth of knowledge generated in a specific field should be organized to illustrate for scholars. Furthermore, in recent years, some bibliometric researchers conducted their studies on examining a specific journal's publications and these researches were mainly focused on publications of top-tier journals (e.g. Cunill et al,. 2019; Mulet-Forteza et al., 2018; Sharma et al., 2020). As one of the top-tier journals in food, tourism, and hospitality, BFJ offers a wide range of knowledge about food and its specific topics. Although the significance of this journal's reputation in the relevant scholarly area and many generated contents, no study examines all documents (2010-2020) published on BFJ by bibliometric analysis. To respond to this research gap and present all publications' summaries, this research attempts to examine the BFJ by using bibliometric and visualization analysis. Thus, the originality of this research can be regarded as one of the first research that tackles this journal by these analysis.

The main research findings indicated that 2019 and 2020 were the most productive year of the BFJ when compared with other years. This is clear that the journal will increase its number of publications 
in the next years. Moreover, BFJ has also received much attention from researchers and scholars who are interested between the food supply chain and food safety. This is evidence that this trend will grow in the coming years because most productive researchers published these topics in 2019 and 2020. The majority of the most productive researchers and organizations are mainly from European countries and the USA. This result illustrates that BFJ is dominated by scholars from Europe and the USA. In addition, these publications are distributed among developed destinations worldwide. However, countries that publish the least number of studies are in the African continent. From the perspective of most cited documents, it seems that most of them are quantitative studies and the most cited study was published in 2011 and has been cited 156 times by other researchers. Generally, the most cited documents tackled organic food products, organic food consumption, and consumer choice.

According to the co-occurrence of author keywords, it was indicated that most of the papers were related to the area of consumer behavior, food safety, food products, food industry, food, nutrition, organic food, sustainability, and consumer. It is well acknowledged that consumer behavior research will be so popular in different tourism and hospitality areas (Gursoy, 2018). As illustrated in this research, the most dominant common keyword among research was regarded as consumer behavior. Additionally, co-authorship of countries indicated that co-authorship network differ among countries from different continents such as Europe Asia, and America. Finally, According to the Cocitation of authors cited in the BFJ, in the period 2010 and 2020, 46,427 authors were cited by BFJ papers. The co-citation map showed that the most cited author by BFJ's authors was Grunert K. G.

Based on all obtained results, it is understood that $\mathrm{BFJ}$ is a constantly growing and leading journal in general. In addition, since all documents published in the last 11 years have been analyzed, the results obtained in this study may be important in terms of giving an idea to academicians and researchers who research food.

This study also has some theoretical and managerial contributions. This paper has identified major themes of food research and prominent studies related to food in terms of managerial contributions. While pioneer food tourism stakeholders develop marketing strategies, they should consider essential researches and authors outlined in the current study. In terms of theoretical contribution, the most studied concepts related to food researches were determined. Moreover, the most contributing authors, countries, journals and institutions have been identified. The results of this study can guide researchers who are interested on food. In summary, the current study can help the authors come up with new topics.

\section{Limitations and Future Research Lines}

There are some limitations of this study to be considered for future research. First, the purpose of this study is to examine papers published on BFJ at a certain period (2010-2020). Therefore, future researches can overview other periods of $\mathrm{BFJ}$ by using other techniques of the bibliometric method. Second, this study tackled all topics of papers in the journal. Future research can overcome this issue by reviewing some specific areas such as consumer behavior, wine tourism, halal food, etc. Third, this research focused on only BFJ. Hence, in the future, it is suggested that scholars may employ bibliometric analysis in different food journals by comparing it with our research findings. Lastly, Vosviewer was used in this study. Therefore, in other studies preferably different software can be used.

\section{References}

Abramo, G., D’Angelo, C. A., \& Caprasecca, A. (2009). Allocative efficiency in public research funding: Can bibliometrics help?. Research Policy, 38 (1), 206-215.

Aertsens, J., Mondelaers, K., Verbeke, W., Buysse, J., \& Van Huylenbroeck, G. (2011). The influence of subjective and objective knowledge on attitude, motivations and consumption of organic food. British Food Journal, 113 (11), 1353-1378.

Akova, O., Cifci, İ., Atsiz, O., \& Gezeroglu, B. (2016). Understanding the motivational factors of dining out: a study at Fatih Kadinlar Bazaar in Istanbul. Tourismos, 11(1), 19-36.

Al-Swidi, A., Huque, S. M. R., Hafeez, M. H., \& Shariff, M. N. M. (2014). The role of subjective norms in theory of planned behavior in the context of organic food consumption. British Food Journal, $116(10), 1561-1580$.

Atsız, O., Cifci, I., \& Law, R. (2021). Understanding food experience in sharing-economy platforms: Insights from Eatwith and Withlocals. Journal of Tourism and Cultural Change, 1-26.

Borgman, C. L., \& Furner, J. (2002). Scholarly Communication and Bibliometrics. Annual Review of Information Science and Technology, 36 (1), 3-72 
Broadus, R. N. (1987). Toward a definition of bibliometrics. Scientometrics, 12, 373-379.

Chen, H., Jiang, W., Yang, Y., Yang, Y., \& Man, X. (2017). State of the art on food waste research: A bibliometrics study from 1997 to 2014. Journal of Cleaner Production, 140, 840-846.

Çif̧̧i, I., Atsız, O., \& Gupta, V. (2021). The street food experiences of the local-guided tour in the mealsharing economy: the case of Bangkok. British Food Journal, 1-19.

Clarivate. (2021). Journal citation reports. Retrieved from

https://apps.clarivate.com/jif/home/?journal=BRI $\mathrm{T}$ (accessed 28 January 2021).

Cooper, I. D. (2015). Bibliometrics basics. Journal of the Medical Library Association: JMLA, 103 (4), 217218.

Cronin, B. (2001). Bibliometrics and beyond: some thoughts on web-based citation analysis. Journal of Information Science, 27(1), 1-7.

Cunill, O. M., Salvá, A. S., Gonzalez, L. O., \& MuletForteza, C. (2019). Thirty-fifth anniversary of the International Journal of Hospitality Management: A bibliometric overview. International Journal of Hospitality Management, 89-101.

Daim, T. U., Rueda, G., Martin, H., \& Gerdsri, P. (2006). Forecasting emerging technologies: Use of bibliometrics and patent analysis. Technological Forecasting and Social Change, 73 (8), 981-1012.

Dimitri, C., \& Dettmann, R. L. (2012). Organic food consumers: What do we really know about them?. British Food Journal, 114 (8), 1157-1183.

Donthu, N., Kumar, S., \& Pattnaik, D. (2020). Forty-five years of Journal of Business Research: A bibliometric analysis. Journal of Business Research, 1-14.

Dora, M., Van Goubergen, D., Kumar, M., Molnar, A., \& Gellynck, X. (2014). Application of lean practices in small and medium-sized food enterprises. British Food Journal, 125-141.

Ellegaard, O., \& Wallin, J. A. (2015). The bibliometric analysis of scholarly production: How great is the impact?, Scientometrics, 1809-1831.

Ellis, A., Park, E., Kim, S., \& Yeoman, I. (2018). What is food tourism?. Tourism Management, 68, 250263.

Emerald. (2021). Journal description. Retrieved from https://www.emeraldgrouppublishing.com/journa l/bfj?_ga=2.109521029.1824282012.16120736921529162381.1611620981 (accessed 28 January 2021).
Evren, S., \& Kozak, N. (2014). Bibliometric analysis of tourism and hospitality related articles published in Turkey. Anatolia, 25 (1), 61-80.

Franceschelli, M. V., Santoro, G., \& Candelo, E. (2018). Business model innovation for sustainability: A food start-up case study. British Food Journal, 120 (10), 2483-2494.

Gaviria-Marin, M., Merigo, J. M., \& Popa, S. (2018). Twenty years of the Journal of Knowledge Management: A bibliometric analysis. Journal of Knowledge Management, 22 (8), 1655-1687.

Ghent University. (2021). Programmes. Retrieved from https://www.ugent.be/en/programmes (accessed 30 January 2021)

Griffith, C. J., Livesey, K. M., \& Clayton, D. (2010a). The assessment of food safety culture. British Food Journal, 112 (4), 439-456.

Griffith, C. J., Livesey, K.M. \& Clayton, D. (2010b). Food safety culture: The evolution of an emerging risk factor?. British Food Journal, 112 (4), 426-38.

Gursoy, D. (2018). Future of hospitality marketing and management research. Tourism Management Perspectives, 25, 185-188.

Hall, C. M. (2011). Publish and perish? Bibliometric analysis, journal ranking and the assessment of research quality in tourism. Tourism Management, 32 (1), 16-27.

Hall, C. M., \& Sharples, L. (2003). The consumption of experiences or the experience of consumption? An introduction to the tourism of taste. In C.M. Hall, L. Sharples, R. Mitchell, N. Macionis, B. Cambourne (Eds.), Food tourism around the world, Routledge, New York.

Horst, H., Pascucci, S., \& Bol, W. (2014). The 'dark side' of food banks? Exploring emotional responses of food bank receivers in the Netherlands. British Food Journal, 116 (9), 1506-1520.

Köseoglu, M. A., Sehitoglu, Y., \& Parnell, J. A. (2015). A bibliometric analysis of scholarly work in leading tourism and hospitality journals: The case of Turkey. Anatolia, 26 (3), 359-371.

Kumar, S., Sureka, R., \& Vashishtha, A. (2020). The Journal of Heritage Tourism: A bibliometric overview since its inception. Journal of Heritage Tourism, 15 (4), 365-380.

Kurtz, M. J., \& Bollen, J. (2010). Usage bibliometrics. Annual Review of Information Science and Technology, 44 (1), 1-64.

Liu, L., \& Mei, S. (2016). Visualizing the GVC research: A co-occurrence network based bibliometric analysis, Scientometrics, 109 (2), 953-977.

Lyu, V. C., Lai, I. K. W., Ting, H., \& Zhang, H. (2020). Destination food research: A bibliometric citation 
review (2000-2018). British Food Journal, 122 (6), 2045-2057.

Martínez-López, F. J., Merigó, J. M., Valenzuela, L., \& Nicolás, C. (2018). Fifty years of the European journal of marketing: A bibliometric analysis. European Journal of Marketing, 439-468.

Mavric, B., Öğretmenoğlu, M., \& Akova, O. (2021). Bibliometric Analysis of Slow Tourism. Advances in Hospitality and Tourism Research, 9 (1), 157178.

McBurney, M. K., \& Novak, P. L. (2002). What is bibliometric and why should you care? In: Proceedings of the Professional Communication Conference, 108-114.

Merigó, J. M., Mulet-Forteza, C., Valencia, C., \& Lew, A. A. (2019). Twenty years of Tourism Geographies: A bibliometric overview. Tourism Geographies, 21 (5), 881-910.

Mokhtari, H., Soltani-Nejad, N., Mirezati, S. Z., \& Saberi, M. K. (2020). A bibliometric and altmetric analysis of Anatolia: 1997-2018. Anatolia, 31 (3), 406-422.

Mongeon, P., \& Paul-Hus, A. (2016). The journal coverage of Web of Science and Scopus: A comparative analysis. Scientometrics, 106 (1), $213-228$.

Morris, S., DeYong, C., Wu, Z., Salman, S., \& Yemenu, D. (2002). DIVA: A visualization system for exploring document databases for technology forecasting, Computers \& Industrial Engineering, 43 (4), 841-862.

Mulet-Forteza, C., Martorell-Cunill, O., Merigó, J. M., Genovart-Balaguer, J., \& Mauleon-Mendez, E. (2018). Twenty five years of the Journal of Travel \& Tourism Marketing: A bibliometric ranking, Journal of Travel \& Tourism Marketing, 35 (9), 1201-1221.

Narin, F. (1994). Patent bibliometrics. Scientometrics, $30(1), 147-155$.

Nofima. (2021). Home. Retrieved from https://nofima.no/en/about-us/ (accessed 30 January 2021)

Okumus, B., Koseoglu, M. A., \& Ma, F. (2018). Food and gastronomy research in tourism and hospitality: A bibliometric analysis. International Journal of Hospitality Management, 73, 64-74.

Osareh, F. (1996). Bibliometrics, citation analysis and co-citation analysis: A review of literature I. Libri, 46 (3), 149-158.

Ozsoy, Z., \& Demir, E. (2018). Which bariatric procedure is the most popular in the world? A bibliometric comparison. Obesity Surgery, 28 (8), 2339-2352.

Park, H. W., Yoon, J., \& Leydesdorff, L. (2016). The normalization of co-authorship networks in the
Mert Öğretmenoğlu, Sevinç Göktepe, Ozan Atsız

bibliometric evaluation: the government stimulation programs of China and Korea. Scientometrics, 109 (2), 1017-1036.

Patra, S. K., Bhattacharya, P., \& Verma, N. (2006).Bibliometric study of literature on bibliometrics. DESIDOC Journal of Library \& Information Technology, 26 (1), 27-32.

Pearson, D., Henryks, J., Trott, A., Jones, P., Parker, G., Dumaresq, D., \& Dyball, R. (2011). Local food: understanding consumer motivations in innovative retail formats. British Food Journal, $113(7), 886-899$.

Ponomariov, B., \& Boardman, C. (2016). What is coauthorship?, Scientometrics, 109 (3),1939-1963.

Principato, L., Secondi, L., \& Pratesi, C. A. (2015). Reducing food waste: an investigation on the behaviour of Italian youths. British Food Journal, $117(2), 731-748$

Pritchard, A. (1969). Statistical bibliography or bibliometrics?, Journal of Documentation, 25 (4),348-349.

Qiu, J. P., Dong, K., \& Yu, H. Q. (2014). Comparative study on structure and correlation among author co-occurrence networks in bibliometrics. Scientometrics, 101 (2), 1345-1360.

Röös, E., \& Tjärnemo, H. (2011). Challenges of Carbon Labelling of Food Products: A Consumer Research Perspective, British Food Journal, 113 (8), 982 996.

Santoro, G., Vrontis, D., \& Pastore, A. (2017). External knowledge sourcing and new product development: evidence from the Italian food and beverage industry. British Food Journal, 119(11), 2373-2387.

Schwert, G. W. (1993). The journal of financial economics: A retrospective evaluation (19741991). Journal of Financial Economics, 33 (3), 369-424.

Scimagojr. (2021). British Food Journal. Retrieved fromhttps://www.scimagojr.com/journalsearch.ph $\mathrm{p} ? \mathrm{q}=144664 \& \mathrm{tip}=$ sid\&clean $=0$ (accessed 28 January 2021).

Scopus. (2021). Source details. Retrieved from https://www.scopus.com/sourceid/144664?origin= resultslist (accessed 28 January 2021).

Sharma, P., Singh, R., Tamang, M., Singh, A. K., \& Singh, A. K. (2020). Journal of teaching in travel \& tourism: A bibliometric analysis. Journal of Teaching in Travel \& Tourism, 1-22.

Silvennoinen, K., Katajajuuri, J. M., Hartikainen, H., Heikkilä, L., \& Reinikainen, A. (2014). Food waste volume and composition in Finnish households. British Food Journal, 116 (6), 10581068 . 
Tarasuk, V., Dachner, N., \& Loopstra, R. (2014). Food banks, welfare and food insecurity in Canada. British Food Journal, 1405-1417.

Teng, C. C., \& Wang, Y. M. (2015). Decisional factors driving organic food consumption. British Food Journal, 117 (3), 1066-1081.

Thelwall, M. (2008). Bibliometrics to webometrics. Journal of Information Science, 34 (4), 605-621.

Universidade Federal De Lavras. (2021). The University. Retrieved from available at: http://ufla.br/en/ufla/ (accessed 30 January 2021).

University of Turin. (2021). Departments. Retrieved from https://en.unito.it/aboutunito/structures/departments (accessed 30 January 2021).

Van Eck, N. J., \& Waltman, L. (2010). Software survey: VOSviewer, a computer program for bibliometric mapping, Scientometrics, 523-538.

Van Leeuwen, T. (2006). The application of bibliometric analyses in the evaluation of social science research: Who benefits from it, and why it is still feasible. Scientometrics, 133-154.

Vanhonacker, F., Lengard, V., Hersleth, M., \& Verbeke, W. (2010). Profiling European traditional food consumers. British Food Journal, 871-886.

Vila-Lopez, N., \& Küster-Boluda, I. (2020). A bibliometric analysis on packaging research: Towards sustainable and healthy packages. British Food Journal, 123 (2), 684-701.

Vishwakarma, P., \& Mukherjee, S. (2019). Forty-three years journey of Tourism Recreation Research: a bibliometric analysis. Tourism Recreation Research, 44 (4), 403-418.

Vosviewer. (2020). Home. Retrieved from https://www.vosviewer.com/ (accessed 10 September 2020).

Vrontis, D., Bresciani, S., \& Giacosa, E. (2016). Tradition and innovation in Italian wine family businesses. British Food Journal, 118 (8), 1883-1897.

Wageningen University and Research. (2021). Programmes. Retrieved from https://www.wur.nl/en/EducationProgrammes.htm (accessed 30 January 2021).

Wang, X., Xu, Z., \& Škare, M. (2020). A bibliometric analysis of Economic Research-Ekonomska Istraživanja (2007-2019). Economic ResearchEkonomska Istraživanja, 33 (1), 865-886.

Wiedmann, K. P., Hennigs, N., Behrens, S. H., \& Klarmann, C. (2014). Tasting green: An experimental design for investigating consumer perception of organic wine. British Food Journal, $116(2), 197-211$
Xie, B., Wang, L., Yang, H., Wang, Y., \& Zhang, M. (2015). Consumer perceptions and attitudes of organic food products in Eastern China. British Food Journal, 117 (3), 1105-1121.

Xu, Z., \& Yu, D. (2019). A Bibliometrics analysis on big data research (2009-2018). Journal of Data, Information and Management, 1 (1), 3-15.

Zakowska-Biemans, S. (2011). Polish consumer food choices and beliefs about organic food. British Food Journal, 113 (1), 122-137. 


$$
\text { 2022, } 7 \text { (1): 55-67 }
$$

https://doi.org/10.31822/jomat.2022-7-1-67

\title{
INFO PAGE
}

\section{A bibliometric analysis of food studies: Evidence from British Food Journal}

\begin{abstract}
The objective of the current study is to overview the British Food Journal publications from 2010 to 2020 . To address our purpose, bibliometric and visualization analyses were used. Firstly, a total of 1892 documents published from 2010 to 2020 in the British Food Journal (BFJ) was obtained from the Web of Science database (WoS). Then, the analyses were made by running VOS viewer software. In the process of analyzing data, we have principally considered some bibliometric indicators such as the number of annual publications, the most productive organizations, the most cited papers, the most contributing countries, the most productive authors, the co-occurrence of author keywords, the co-authorship of countries, and the co-citation of authors. The results show that BFJ is one of the leading and prominent journals with the number of publications increasing each year according to the basic indicators mentioned above. Further to this, the most productive and contributing authors, institutions, and countries are mainly from European countries. The most common researched fields according to the co-occurrence of author keywords are listed as "consumer behavior, food safety, food products, food industry, food, nutrition, organic food, sustainability, and consumer".
\end{abstract}

Keywords: Food, Food studies, British Food Journal, Bibliometric analysis, vOSviewer software, Web of Science

\section{Authors}

$\begin{array}{llc}\text { Full Name } & \text { Author contribution roles } & \text { Contribution rate } \\ \text { Mert Öğretmenoğlu: Conceptualization, Methodology, Software, Writing - Review \& Editing, Visualization, Supervision, } & 40 \%\end{array}$

Sevinç Göktepe : Conceptualization, Methodology, Writing - Review \& Editing,

Author statement: Author(s) declare(s) that All procedures performed in studies involving human participants were in accordance with the ethical standards of the institutional and/or national research committee and with the 1964 Helsinki declaration and its later amendments or comparable ethical standards. Declaration of Conflicting Interests: The author(s) declared no potential conflicts of interest with respect to the research, authorship, and/or publication of this article 